RURAL SUSTAINABILITY RESEARCH 46(341), 2021

ISSN - 2256-0939

(c) Latvia University of Life Sciences and Technologies, all rights reserved http://www.Ilu.Iv/en/

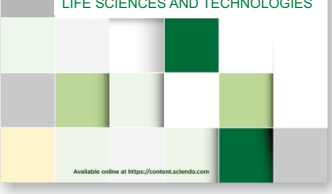

\title{
Strategic Potential of Agricultural Waste as a Feedstock for Biofuels Production in Ukraine
}

\author{
Dina Tokarchuk, *Natalia Pryshliak, Andrii Shynkovych, Kateryna Mazur \\ Vinnytsia National Agrarian University, 3 Sonyachna street, Vinnytsia, Ukraine
}

\begin{abstract}
Ukraine's agriculture is a leading sector of the national economy. Ukraine has a significant area $\left(603628 \mathrm{~km}^{2}\right), 70.9 \%$ of which are agricultural lands. Quality soil and good climatic conditions create favorable conditions for the development of crop and livestock production. The generation of a large amount of organic waste from agriculture opens wide opportunities for the development of the biogas technologies. The aim of the paper is to identify the main waste management trends in Ukraine based on data on waste generation and waste management and to calculate the strategic potential of agricultural waste as a feedstock for biofuels production. The resource potential of crop, livestock and processing waste has been considered and the necessity of its use for energy purposes has been substantiated. It has been determined that the greatest potential of agricultural waste that can be used for biogas production in Ukraine is concentrated in crop production. The livestock industry and processing enterprises also have a powerful feedstock base for biogas production. It has been determined that the agroindustrial sector of Ukraine produces significant amount of waste. As a result of the study, it has been found that the potential volume of biogas production from agricultural waste can replace $36.1 \%$ of natural gas consumption in Ukraine.
\end{abstract}

Keywords: agriculture waste, primary plant waste, livestock waste, potential, biofuels, efficiency.

\section{Introduction}

The waste problem is complex and multifaceted both in Ukraine and around the world. In Ukraine, it became necessary to resolve the critical situation that has evolved with the formation, accumulation, storage, processing and disposal of waste. Such a situation has been characterized by the further development of environmental threats. The problem of waste accumulation and recycling combines environmental, resource and energy aspects, since waste not only pollutes the environment, but also contains useful components. The problem of efficient waste management has been often hampered by a lack of public and commercial interests. Therefore, the problem of using waste as feedstock for biogas production requires a detailed study.

Agriculture today uses production technologies that generate a significant amount of waste, ineffective management of which often leads to negative environmental consequences. The problem of the accumulation of agricultural waste in Ukraine is of a particular importance due to lack of an adequate response to its challenges for a long time.

Such circumstances lead to a deepening of environmental crisis and an aggravation of the socio-economic situation in society and necessitate reform and development, considering the domestic and world experience of the entire legal and economic system that regulates the use of natural resources in general and the management of waste from agricultural enterprises in particular. The problem of waste, especially animal waste, is one of the most important environmental problems and is significant in terms of resources.

A high level of agricultural waste generation and low rates of its use as a secondary feedstock have led to the fact that in Ukraine annually significant volumes of organic waste accumulate in agriculture, of which only a small part is used as feedstock for biofuel production, the rest end up in the soil and ground water, while polluting the environment.

The difference between the situations with agricultural waste in Ukraine in comparison with other developed countries lies in the large volumes of organic waste generation and in the absence of a practice of handling them. At the same time, effective management of animal and crop waste is an indispensable feature of all economies of developed countries. 
At the same time, the potential of agricultural waste can be redirected to the bioenergy sector, in particular into the production of biogas by methane fermentation.

In order to reduce the dependence on fossil energy sources in Ukraine, the need to develop its own alternative energy fuels production has arisen (Kulyk, et al., 2020). It is possible to use energy crops and agriculture waste in order to produce different types of biofuel for the replacement of traditional petroleum fuel. Kaletnik, Pryshliak V., \& Pryshliak N., (2019) have investigated the influence of public policy in the sphere of biofuel production and consumption on energy, environment and food security of the state.

Agricultural wastes are non-product outputs of production and processing of agricultural products that may contain material that can benefit people but whose economic values are less than the cost of storage, transportation, and processing for beneficial use. Estimates of agricultural waste arising are rare, but they are generally thought of as contributing a significant proportion of the total waste matter in the developed world (Obil, Ugwuishiwu, \& Nwakaire, 2016).

According to Kaletnik, Honcharuk, \& Okhota (2020), Berezyuk, Tokarchuk, \& Pryshliak (2019a, 2019b), Zulauf, et al. (2018), waste has a valuable secondary resource potential, including energy potential which is not fully used because of lack of awareness and proper marketing.

The European experience of waste management has been developed by Castillo-Gimenez, Montanes, \& Picazo-Tade, 2019. They have studied a composite indicator of waste performance including landfill, incineration, recycling, and composting and digestion as treatment operations.

Agricultural wastes have become an increasing concern in recent years, as they may cause significant environmental problems; however, they may also be used for several beneficial purposes, as feedstock for energy production, and for chemical recovery and chemical or dye adsorption (Zhang, Gonzalez, Davies, \& Liu, 2012).

Scientists (Sadh, Duhan S., \& Duhan J., 2018) note that the use of agro-industrial wastes as raw materials can help to reduce both the production cost and the pollution load from the environment. Agro-industrial wastes are used for manufacturing of biofuels, enzymes, vitamins, antioxidants, animal feed, antibiotics, and other chemicals through solid state fermentation (SSF).
The theoretical and practical aspects of non-waste agricultural production development using animal waste and crop residues fermented in biogas plants are revealed by Kaletnik, Honcharuk, \& Okhota, 2020.

The paper is a continuation of the authors' research on socio-economic and environmental benefits of biofuel production development from agricultural waste in Ukraine (Pryshliak \& Tokarchuk, 2020) and efficiency of waste use for biogas production (Pryshliak, 2019; Tokarchuk, et al., 2020).

Based on the urgency of bioenergy development in Ukraine the marketing study of the potential, awareness and current status of the use of agricultural waste to ensure the energy autonomy of agricultural enterprises has been made (Pryshliak, et al., 2020).

The purpose of this study is to identify the main waste trends in Ukraine based on data on waste generation and management; to calculate the strategic potential of agricultural waste as a feedstock of biogas production.

\section{Materials and Methods}

The work was based on the use of general scientific methods of cognition and methodological apparatus of economic research in agriculture and agro-industrial complex: a systematic approach - in the analysis of scientific works on the subject of research; abstract-logical method in determining the aims of the study and the formation of conclusions; analytical and statistical-economic methods in the study of waste management efficiency and opportunities for its energy use; calculation and design - in assessing and forecasting the use of waste for biogas production.

\section{Results and Discussion}

In general, Ukraine has a significant volumes of waste generation, which is associated with the use of outdated production technologies and low rates of implementation of effective resource-saving technologies.

As of $2019,441,516.5$ thousand tonnes of waste have been generated in Ukraine $(129,248.9$ thousand t more than in 2015 (Table 1)).

Generation and management of waste in Ukraine, 2015-2019, thsd. $t$

\begin{tabular}{|c|c|c|c|c|c|}
\hline $\begin{array}{c}\text { Year / waste } \\
\text { class }\end{array}$ & Generated & Utilized & Incinerated & $\begin{array}{c}\text { Waste accumulated } \\
\text { in the specially } \\
\text { designated places } \\
\text { or facilities }\end{array}$ & $\begin{array}{c}\text { The total amount of waste } \\
\text { accumulated during operation in } \\
\text { specially designated places or } \\
\text { objects (waste disposal sites) }\end{array}$ \\
\hline 2015 & 312267.6 & 92463.7 & 1134.7 & 152295.0 & 152295.0 \\
\hline $\begin{array}{c}\text { including } \\
\text { I-III hazard } \\
\text { classes waste }\end{array}$ & 587.3 & 314.5 & 5.8 & 78.6 & 12055.0 \\
\hline 2016 & 295870.1 & 84630.3 & 1106.1 & 157379.3 & 12393923.1 \\
\hline
\end{tabular}




\begin{tabular}{|c|c|c|c|c|c|}
\hline $\begin{array}{c}\text { including } \\
\text { I-III hazard } \\
\text { classes waste }\end{array}$ & 621.0 & 337.9 & 6.2 & 111.7 & 12102.4 \\
\hline 2017 & 366054.0 & 100056.3 & 1064.3 & 169801.6 & 12442168.6 \\
\hline $\begin{array}{c}\text { including } \\
\text { I-III hazard } \\
\text { classes waste }\end{array}$ & 605.3 & 305.5 & 8.7 & 107.1 & 12197.6 \\
\hline 2018 & 352333.9 & 103658.1 & 1028.6 & 169523.8 & 12217.2 \\
\hline $\begin{array}{c}\text { including } \\
\text { I-III hazard } \\
\text { classes waste }\end{array}$ & 627.4 & 276.5 & 11.9 & 114.9 & 15398649.4 \\
\hline 2019 & 441516.5 & 108024.1 & 1059.0 & 238997.2 & 12305.1 \\
\hline $\begin{array}{c}\text { including } \\
\text { cl-III hazard }\end{array}$ & 553.0 & 252.1 & 10.6 & 93.3 & 2892733.6 \\
\hline $\begin{array}{c}2019 \text { compared } \\
\text { to 2015 p. (+/-) }\end{array}$ & 129248.9 & 15560.4 & -75.7 & 86702.2 & \\
\hline
\end{tabular}

Source: State Statistics Service of Ukraine

Waste generation from agriculture, forestry and fisheries and its share in waste generation by type of economic activity and households for 2010-2019 in Ukraine is shown in Figure 1.

thsd.t

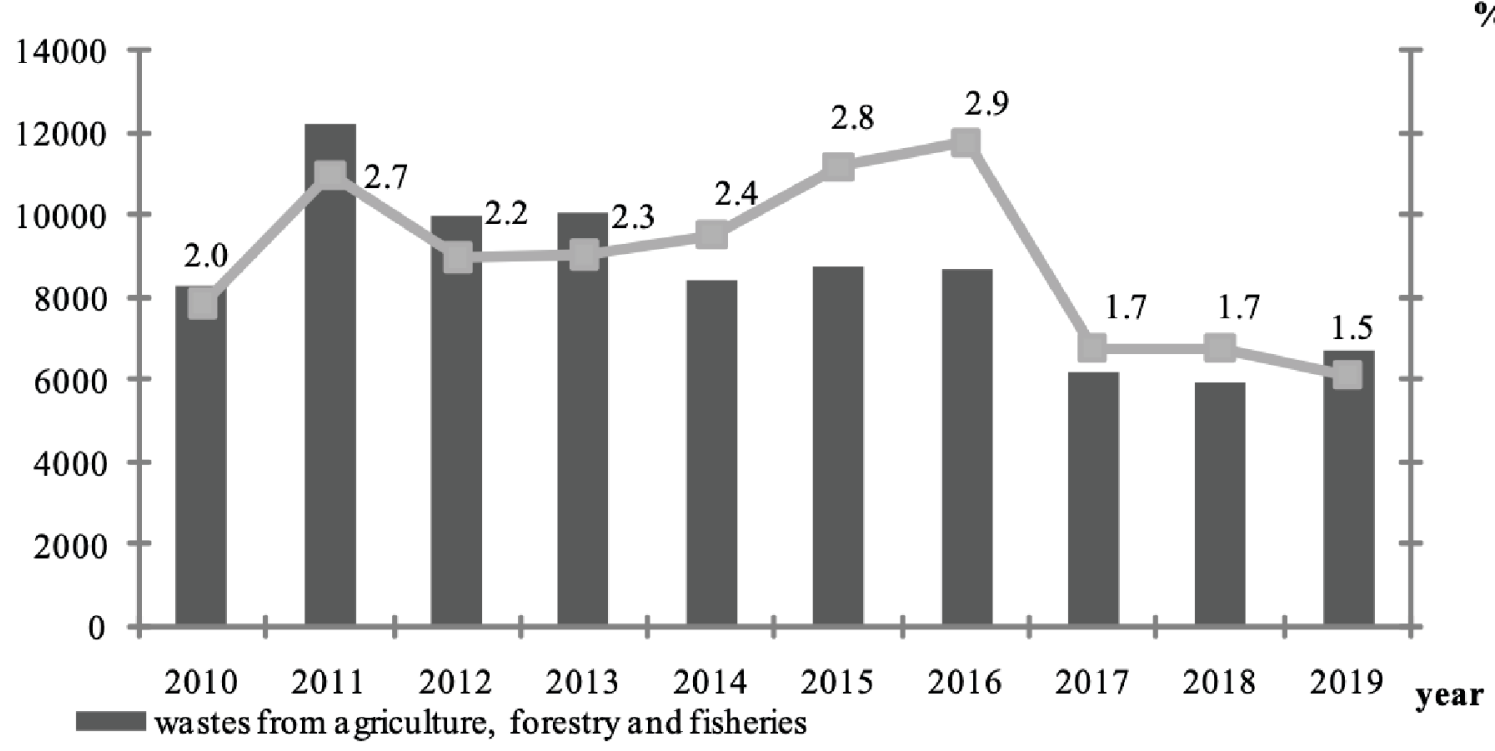

share of a gricultural, forestry and fishery waste in waste by types of economic activity and households

Figure 1. Waste generation from agriculture, forestry and fisheries and its share in waste by economic activity and households in Ukraine, 2010-2019, thsd. t, \%.

Source: State Statistics Service of Ukraine 
The volumes of waste generated by the agricultural sector differ each year; however, they tend to decrease over the last 6 years. Its share varies within 3-1.5\%.

According to the State Statistics Service of Ukraine in 2019 in the structure of the total amount of waste generation by type of economic activity the share of agricultural waste was $1.53 \%$; waste from the extractive industry was $88.46 \%$; processing industry waste was $6.97 \%$; waste from supply of electricity, gas, steam and air conditioning waste was $1.35 \%$; the amount of collected waste received from households was $1.34 \%$; waste from other economic activities was $0.36 \%$ (Figure 2 ).

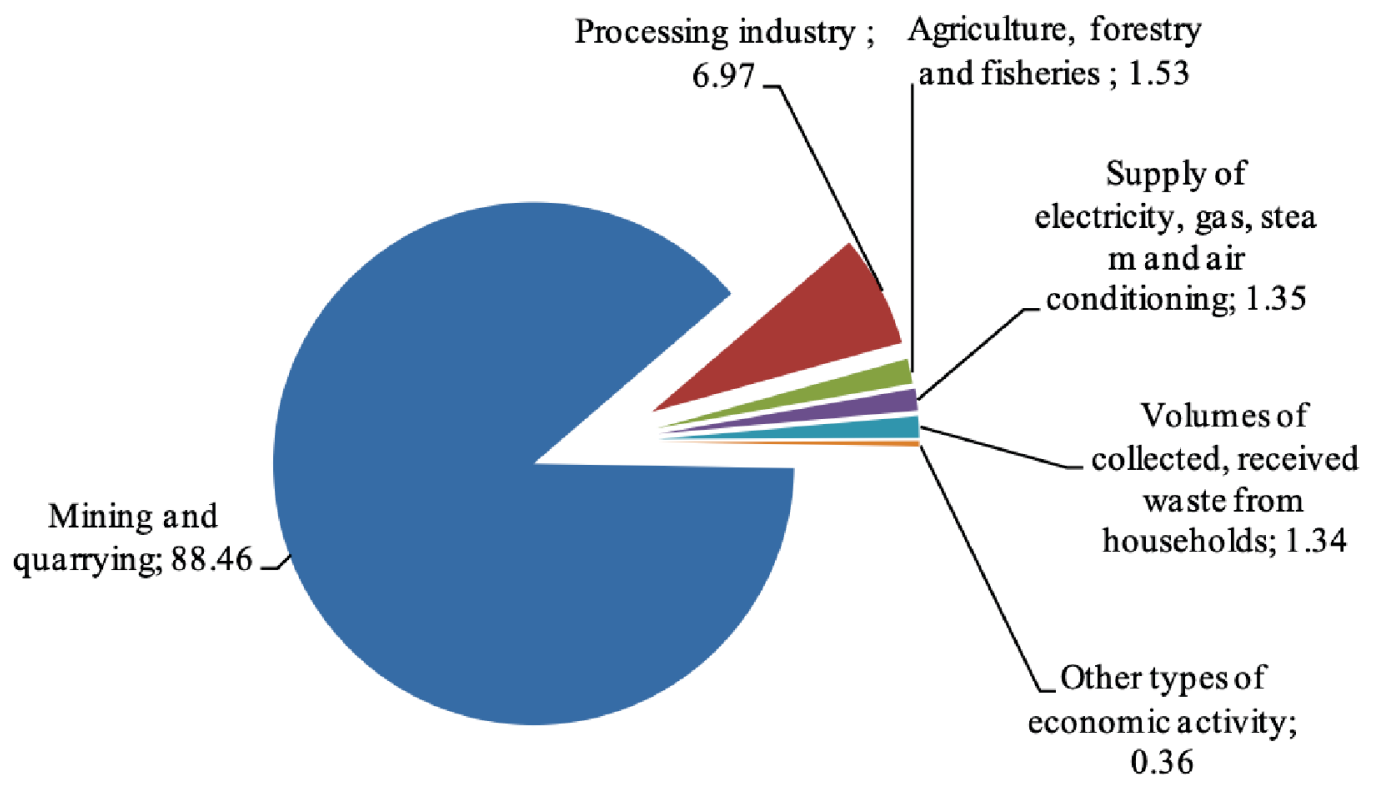

Figure 2. Waste generation in Ukraine by economic activity, 2019, \%. Source: State Statistics Service of Ukraine

The intensification of agricultural production and the expansion of agricultural land have led to an increase in the amount of waste and its impact on the environment. Several types of agricultural production waste, in particular, crop waste, animal and poultry waste, and biowaste (carcasses of animals and poultry), cause a potential negative impact on the environment.

Agricultural waste in Ukraine is divided into animal waste and crop waste. According to statistical data in 2019 more than 13,500,000 t of agricultural waste were generated, the massive ones are:

- vegetable waste (8068.6 thousand t, or $66.6 \%$ );

- animal excrement, urea and manure (3612.9 thousand t, or $29.8 \%$ );

- animal waste and mixed food waste (441.0 thousand $t$, or $3.6 \%)$.

However, statistical data do not fully reflect the real state situation.

The crop industry annually generates a large amount of various wastes and residues. Waste is divided into primary, i.e. the one which is generated directly during the harvest of crops, and secondary - the one that is generated during the processing of crops at enterprises. Primary waste includes straw from cereals and other crops, wastes from the production of maize for grain and sunflower (stems, rods, baskets, etc.). Secondary wastes are sunflower husks, buckwheat and rice husks, sugar beet pulp and others. Part of the waste and residues is used for the needs of agriculture itself (organic fertilizer, litter and livestock feed), part - in other sectors of the economy, and the rest of waste biomass remains unused and is often disposed of (burned in the field, taken to landfill) without benefit. Big amount of the unused biomass is appropriate to be involved in energy production. At the same time, the important issue is what part of agricultural waste and residues can be used for energy needs without causing a negative impact on soil fertility (Heletukha, Zhelyezna, 2014).

Table 2 shows the generation of the main primary crop waste in Ukraine, based on the gross harvest of major crops and the waste yield. 
Formation of primary plant waste in Ukraine, 2015-2019

\begin{tabular}{|c|c|c|c|c|c|c|c|c|c|c|c|c|c|}
\hline \multirow[b]{2}{*}{ Crop } & \multirow[b]{2}{*}{ 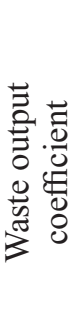 } & \multicolumn{2}{|c|}{2015} & \multicolumn{2}{|c|}{2016} & \multicolumn{2}{|c|}{2017} & \multicolumn{2}{|c|}{2018} & \multicolumn{2}{|c|}{2019} & \multicolumn{2}{|c|}{$\begin{array}{c}2019 \text { to } 2015 \\
(+,-)\end{array}$} \\
\hline & & 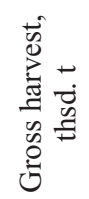 & 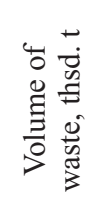 & 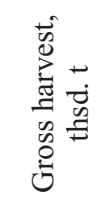 & 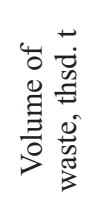 & 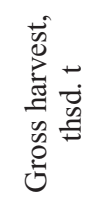 & 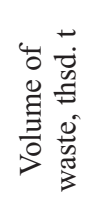 & 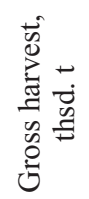 & 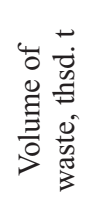 & 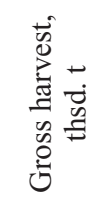 & 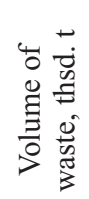 & 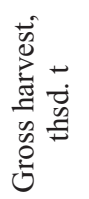 & 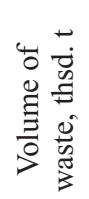 \\
\hline Wheat & 1.0 & 26532 & 26532 & 26099 & 26099 & 26209 & 26209 & 24606 & 24606 & 28328 & 28328 & 1796 & 1796 \\
\hline Barley & 0.8 & 8288 & 6630 & 9436 & 7549 & 8285 & 6628 & 7349 & 5879 & 8917 & 7134 & 629 & 504 \\
\hline Rye & 1.3 & 387 & 503 & 390 & 507 & 505 & 657 & 394 & 512 & 333 & 433 & -54 & -70 \\
\hline Rice & 0.9 & 63 & 57 & 65 & 59 & 64 & 58 & 69 & 62 & 55 & 50 & -8 & -8 \\
\hline Millet & 0.8 & 213 & 170 & 190 & 152 & 84 & 67 & 80 & 64 & 170 & 136 & -43 & -34 \\
\hline Oat & 1.0 & 489 & 489 & 500 & 500 & 471 & 471 & 419 & 419 & 422 & 422 & -67 & -67 \\
\hline $\begin{array}{l}\text { Buck- } \\
\text { wheat }\end{array}$ & 1.9 & 128 & 243 & 176 & 334 & 180 & 342 & 137 & 260 & 85 & 162 & -43 & -82 \\
\hline $\begin{array}{l}\text { Other } \\
\text { cereal } \\
\text { and } \\
\text { legumi } \\
\text { nous } \\
\text { crops }\end{array}$ & 0.7 & 698 & 489 & 1157 & 810 & 1450 & 1015 & 1202 & 841 & 953 & 667 & 255 & 178 \\
\hline $\begin{array}{l}\text { Soya } \\
\text { beans }\end{array}$ & 0.9 & 3931 & 3538 & 4277 & 3849 & 3899 & 3509 & 4461 & 4015 & 3699 & 3329 & -232 & -209 \\
\hline $\begin{array}{l}\text { Winter } \\
\text { rapese } \\
\text { ed and } \\
\text { colza }\end{array}$ & 2.0 & 1738 & 3476 & 1154 & 2308 & 2195 & 4390 & 2751 & 5501 & 3280 & 6560 & 1542 & 3084 \\
\hline $\begin{array}{l}\text { Maize } \\
\text { for } \\
\text { grain }\end{array}$ & 1.3 & 23328 & 30326 & 28075 & 36498 & 24669 & 32070 & 35801 & 46541 & 35880 & 46644 & 12552 & 16318 \\
\hline $\begin{array}{l}\text { Sunflo } \\
\text { wer } \\
\text { (stalks ) }\end{array}$ & 1.9 & 11181 & 21244 & 13627 & 25891 & 12236 & 23248 & 14165 & 26914 & 15254 & 28983 & 4073 & 7739 \\
\hline $\begin{array}{l}\text { Sugar } \\
\text { beet } \\
\text { tops }\end{array}$ & 0.5 & 10331 & 5166 & 14011 & 7006 & 14882 & 7441 & 13968 & 6984 & 10700 & 5350 & 369 & 185 \\
\hline $\begin{array}{l}\text { Sugar } \\
\text { beet } \\
\text { pulp }\end{array}$ & 0.8 & 10331 & 8265 & 14011 & 11209 & 14882 & 11906 & 13968 & 11174 & 10700 & 8560 & 369 & 295 \\
\hline
\end{tabular}

Source: State Statistics Service of Ukraine

About 80 million t of waste are generated annually at the enterprises for production and processing of crop products in the agro-industrial sector. Enterprises generate more than 60 million $\mathrm{t}$ of primary waste from raw materials and harvesting, and 20 million $\mathrm{t}$ of secondary waste from technological processes of converting raw materials into 
Raising livestock and poultry and waste generation in Ukraine

\begin{tabular}{|c|c|c|c|c|c|c|c|c|}
\hline Category & 1991 & 1996 & 2001 & 2006 & 2010 & 2015 & 2020 & $\begin{array}{c}2019 \text { to } \\
1991(+,-)\end{array}$ \\
\hline \multicolumn{9}{|c|}{ Raising livestock and poultry, million heads } \\
\hline Cattle & 24.62 & 17.56 & 9.42 & 6.51 & 4.83 & 3.88 & 3.09 & -21.53 \\
\hline Pigs & 19.43 & 13.14 & 7.65 & 7.05 & 7.58 & 7.35 & 5.73 & -13.70 \\
\hline $\begin{array}{l}\text { Sheep and } \\
\text { goats }\end{array}$ & 8.42 & 4.10 & 1.88 & 1.63 & 1.83 & 1.37 & 1.20 & -7.21 \\
\hline Horses & 0.74 & 0.76 & 0.70 & 0.55 & 0.50 & 0.34 & 0.22 & -0.51 \\
\hline Poultry & 246.10 & 149.75 & 123.72 & 161.99 & 191.45 & 213.34 & 220.49 & -25.62 \\
\hline \multicolumn{9}{|c|}{ Waste generation, million $\mathrm{t}$} \\
\hline Cattle & 251.16 & 179.08 & 96.12 & 66.44 & 49.23 & 39.62 & 31.54 & -219.62 \\
\hline Pigs & 69.94 & 47.32 & 27.55 & 25.39 & 27.28 & 26.46 & 20.62 & -49.32 \\
\hline $\begin{array}{l}\text { Sheep and } \\
\text { goats }\end{array}$ & 9.26 & 4.51 & 2.06 & 1.79 & 2.02 & 1.51 & 1.32 & -7.94 \\
\hline Horses & 5.39 & 5.52 & 5.12 & 4.05 & 3.65 & 2.48 & 1.64 & -3.75 \\
\hline Poultry & 13.54 & 8.24 & 6.80 & 8.91 & 10.53 & 11.73 & 12.13 & -1.41 \\
\hline
\end{tabular}

Source: State Statistics Service of Ukraine

Cattle produce the largest amount of waste in the livestock sector. On average, one animal can generate $28 \mathrm{~kg}$ of manure daily. Thus, one animal produces $10.2 \mathrm{t}$ of manure per year.

Ukraine has seen a declining trend in animal husbandry over the last 30 years: over the years of Ukraine's independence, the number of cattle has decreased more than 8 times. On January 1, 2020, the number of cattle in Ukraine amounted to 3.092 million. This is $7.2 \%$ less than on the same date in 2019, according to official statistics. Experts have already noted that the livestock population has become the lowest in the entire modern history of Ukraine. It is reported that the rate of reduction in agricultural enterprises is significantly lower than in households. Low purchase prices for milk produced in households, the spread of animal diseases, ineffective market controls, capital intensity of production and active migration processes in rural areas (work migration) are among the reasons. At the same time, meat consumption per capita in Ukraine lags significantly behind developed countries. Thus, the average consumption of beefper capita is $7.3 \mathrm{~kg}$ consumption of pork $-19 \mathrm{~kg}$ in Ukraine, while in Germany - 14 and $56 \mathrm{~kg}$, respectively.

Considering that one cow produces $10.2 \mathrm{t}$ of manure per year, manure production in 2020 amounted to 31.538 million t. It should be noted that manure is a valuable by-product ( 1 ton of cattle manure costs USD 10), but fresh manure cannot be used as fertilizer, and during the period of sedimentation it emits a significant amount of methane, polluting both the atmosphere and groundwater.
Pig breeding is a promising supplier of raw materials for biogas production. However, the dynamics of the pig population in Ukraine is also disappointing. At the beginning of 2020, the number of pigs in the country has set a new antirecord -5.72 million heads (of which only 2.42 million heads in households). The gradual reduction in the total pig population in Ukraine is primarily due to the decrease in the number of these animals in households. The greatest decrease in livestock was recorded in the household sector of Vinnitsa, Zakarpattia, Odessa and Ternopil regions of Ukraine.

The number of sheep in Ukraine today in comparison with the heyday of the industry (1990-1991), has decreased by 7 times and currently is about 1.2 million heads. The large-scale sheep industry has become small-scale over the past 20 years. This state of sheep breeding is primarily due to a sharp decline in wool prices, which reduced the interest of producers in its production.

Horse breeding is a specific branch of animal husbandry, the main directions of which in modern conditions are sports, hobbies, human leisure, treatment (hippotherapy). At the beginning of 1991, in Ukraine there were 738.4 thousand heads of horses, 11 state horse factories, 4 racetracks, 132 stud farms, equestrian complexes, schools and clubs. In the first years of independence, the number of horses changed little (1991-2001), but later the domestic horse breeding underwent a significant reduction $(21.9 \%)$ (espewq cially since 2006), which is continuing to this day. On January 1, 2020 , there were 224.4 thousand heads of horses in Ukraine. 
In contrast to cattle, pig, sheep, goat and horse breeding, the volume of which is declining every year, poultry production in Ukraine has a positive trend over the past 5 years. Further growth in sales volumes in the poultry industry is expected to be on average 2-3\% per year. Thus, on January 1,2020 , there were 220.4 million poultry heads in Ukraine. It is also worth notingthat in 2019 poultry meat was in first place in volumes of consumption (25.15 kg per year per capita), pork meat was in second place (12.6 kg per year per capita), and beef was in third place (5.4 kg per year per capita).

The growth of poultry production in Ukraine and the construction of powerful complexes has both positive and negative consequences. The negatives include the rapid growth of poultry waste, which has serious environmental impacts caused by inefficient disposal.

Agricultural waste management of all hazard classes in Ukraine is reflected in the Statistical Yearbook of Ukraine and summarized in Table 4 . The main areas of waste management include: incineration for energy recovery, incineration without energy recovery, utilization, removal to specially designated places or facilities.

Agricultural waste management of all hazard classes of waste in Ukraine, 2015-2019

\begin{tabular}{|c|c|c|c|c|c|c|c|c|c|c|c|c|}
\hline & \multicolumn{2}{|c|}{2015} & \multicolumn{2}{|c|}{2016} & \multicolumn{2}{|c|}{2017} & \multicolumn{2}{|c|}{2018} & \multicolumn{2}{|c|}{2019} & \multicolumn{2}{|c|}{$\begin{array}{l}2019 \text { to } \\
2015+,-\end{array}$} \\
\hline Type of waste & $\begin{array}{l}\stackrel{+}{\vec{D}} \\
\stackrel{0}{\rightleftarrows}\end{array}$ & 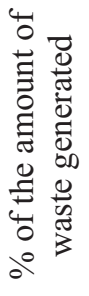 & $\begin{array}{l}+ \\
\stackrel{D}{0} \\
\stackrel{D}{E}\end{array}$ & 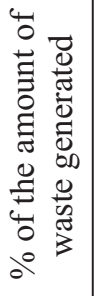 & $\begin{array}{l}+ \\
\stackrel{D}{0} \\
\stackrel{D}{E}\end{array}$ & 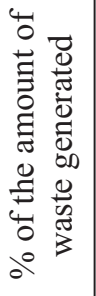 & 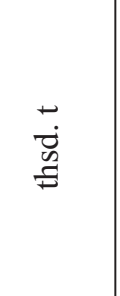 & 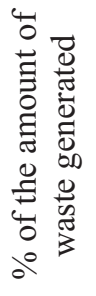 & $\stackrel{+}{\vec{D}}$ & 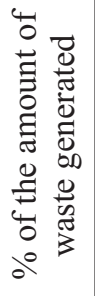 & 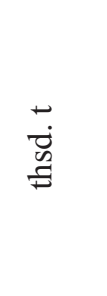 & 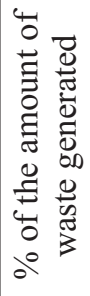 \\
\hline \multicolumn{13}{|c|}{ Incinerated for energy recovery } \\
\hline $\begin{array}{l}\text { Animal waste and } \\
\text { mixed food waste }\end{array}$ & 0.5 & 0.2 & 0.0 & 0.0 & 0.1 & 0.0 & 0.1 & 0.0 & 0.0 & 0.0 & -0.5 & -0.2 \\
\hline $\begin{array}{l}\text { Wastes of plant } \\
\text { origin }\end{array}$ & 445.0 & 13.5 & 392.4 & 10.9 & 406.1 & 13.8 & 386.8 & 12.0 & 423.1 & 14.9 & -21.9 & 1.4 \\
\hline $\begin{array}{l}\text { Animal excrement, } \\
\text { urine and manure }\end{array}$ & - & - & - & - & - & - & - & - & - & - & - & - \\
\hline \multicolumn{13}{|c|}{ Incinerated without energy recovery } \\
\hline $\begin{array}{l}\text { Animal waste and } \\
\text { mixed food waste }\end{array}$ & 1.4 & 0.6 & 2.3 & 0.7 & 4.0 & 1.2 & 9.3 & 3.0 & 11.7 & 4.8 & 10.3 & 4.2 \\
\hline $\begin{array}{l}\text { Wastes of plant } \\
\text { origin }\end{array}$ & 17.0 & 0.5 & 32.6 & 0.9 & 21.9 & 0.8 & 31.9 & 1.0 & 38.1 & 1.3 & 21.1 & 0.8 \\
\hline $\begin{array}{l}\text { Animal excrement, } \\
\text { urine and manure }\end{array}$ & - & - & - & - & - & - & - & - & - & - & - & - \\
\hline \multicolumn{13}{|c|}{ Utilized } \\
\hline $\begin{array}{l}\text { Animal waste and } \\
\text { mixed food waste }\end{array}$ & 220.0 & 86.9 & 315.1 & 95.4 & 316.1 & 98.3 & 295.3 & 96.4 & 230.8 & 94.3 & 10.8 & 7.4 \\
\hline $\begin{array}{l}\text { Wastes of plant } \\
\text { origin }\end{array}$ & 2674.4 & 81.0 & 3158.4 & 88.0 & 2505.1 & 85.1 & 2638.2 & 82.2 & 2361.1 & 83.1 & -313.3 & 2.1 \\
\hline $\begin{array}{l}\text { Animal excrement, } \\
\text { urine and manure }\end{array}$ & 3231.5 & 94.1 & 3146.9 & 98.2 & 2616.5 & 98.1 & 2300.3 & 97.0 & 2407.0 & 98.8 & -824.5 & 4.7 \\
\hline \multicolumn{13}{|c|}{ Removed to specially designated places or facilities } \\
\hline $\begin{array}{l}\text { Animal waste and } \\
\text { mixed food waste }\end{array}$ & 31.3 & 12.4 & 12.9 & 3.9 & 1.5 & 0.5 & 1.7 & 0.6 & 2.3 & 0.9 & -29.0 & -11.5 \\
\hline $\begin{array}{l}\text { Wastes of plant } \\
\text { origin }\end{array}$ & 166.7 & 5.0 & 7.0 & 0.2 & 8.9 & 0.3 & 154.0 & 4.8 & 17.3 & 0.6 & -149.4 & -4.4 \\
\hline $\begin{array}{l}\text { Animal excrement, } \\
\text { urine and manure }\end{array}$ & 200.8 & 5.9 & 58.9 & 1.8 & 51.8 & 1.9 & 72.0 & 3.0 & 30.0 & 1.2 & -170.8 & -4.7 \\
\hline
\end{tabular}

Source: State Statistics Service of Ukraine 
Based on the analysis of Table 4, we can conclude that most agricultural waste in Ukraine was utilized / neutralized/treated (81.0-85.1\% of waste of plant origin and $94.1-98.8 \%$ of animal excrement, urine and manure).

The most common method of plant origin waste management both in Ukraine and in the world is incineration. Volumes of plant origin waste incineration for energy recovery in Ukraine during the studied period did not increase significantly and fluctuated between $10.9-14.9 \%$. On the positive side, the volume of incineration for energy recovery was the largest in 2019.

Positive trends also include a decrease in the volume of waste removed to specially designated places or facilities: animal waste and mixed food waste - from $12.4 \%$ in 2015 to $0.9 \%$ in 2019 ; waste of plant origin - from $5.0 \%$ to $0.6 \%$; animal excrement, urine and manure - from $5.9 \%$ to $1.2 \%$. This indicates an increase in the useful utilization of waste and a reduction in the load on storage places, which has a positive impact on the environment.

The energy use of agricultural waste remains low, much of the bioenergy potential in Ukraine in general is lost. Instead, it can be used efficiently for the production of biofuels, in particular biogas. The range of organic waste suitable for biogas production is quite wide in Ukraine. Almost all types of organic waste can be used as a feedstock for fermentation. First of all, these are agricultural waste of animal (manure) and plant origin (Palamarenko, 2019).

The classification of feedstock for biogas production is shown in Figure 3.

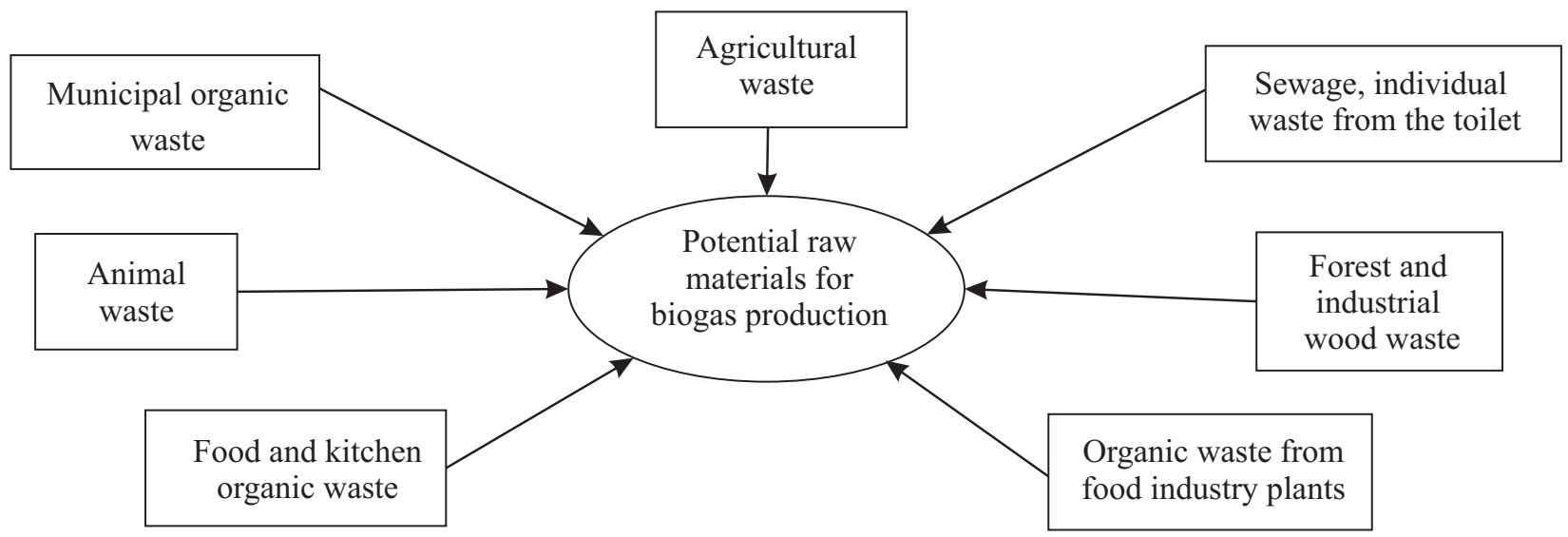

Figure 3. The structure of feedstock for biogas production.

Source: formed by the authors

Table 5 shows the data on the energy potential of crop waste for biogas production.

Table 5

\section{Energy potential of crop waste for biogas production}

\begin{tabular}{|c|c|c|c|}
\hline Type of waste & $\begin{array}{c}\text { Accumulation of total } \\
\text { waste, million } \\
\mathrm{t} / \mathrm{year}\end{array}$ & $\begin{array}{c}\text { Biogas output from } \\
\text { 1 ton of substrate, } \\
\text { cubic meters }\end{array}$ & $\begin{array}{c}\text { Biogas production } \\
\text { potential, million cubic } \\
\text { meters/year }\end{array}$ \\
\hline $\begin{array}{c}\text { Maize: stems, cobs (mixture), } \% \\
\text { crude fiber (30\% for biogas) }\end{array}$ & 14.0 & 451 & 6310.9 \\
\hline Sugar beet ensilage & 5.4 & 90 & 120 \\
\hline Sugar beet pulp & 8.6 & 517 & 1721.1 \\
\hline Soybean waste & 3.3 & 620 & 261.6 \\
\hline Oat waste & 0.4 & 112 & 168.0 \\
\hline Apple pulp & 1.5 & 57 & 56.1 \\
\hline Vegetable waste & 1.0 & $\mathrm{x}$ & 930.2 \\
\hline
\end{tabular}

Source: calculated by the authors 
One of the most important questions is what share of plant waste from agricultural production can be used for energy production, taking into account the needs of crop and livestock production. To get an answer to this question we have considered the existing research on this topic and the practical experience of other countries. For the European Union as a whole, about a dozen studies have been carried out on the energy use of plant waste. According to their results, $25-50 \%$ of the harvest of straw and crop residues of corn for grain, $30-50 \%$ of waste from sunflower production can be used for energy needs, and the rest of the biomass should remain in the fields.

Studies carried out under US conditions have shown that $30-60 \%$ of the total straw and grain corn production waste can be used for energy / biofuel production

(Heletukha\&Zhelyezna, 2014).

The question of the proportion of straw and other plant residues that can be used for energy or biofuel production needs to be decided individually for each farm.

At the same time, all important agroeconomic factors must be taken into account. For Ukraine as a whole, it is possible to offer only general recommendations regarding the proportion of straw and other plant residues available for use as fuel, taking into account the own needs of agriculture: use up to $30 \%$ of the theoretical potential of grain straw and up to $40 \%$ of the theoretical potential of corn production waste for grain and sunflower.

One of the promising types of crop waste is beet pulp, obtained at sugar factories. Previously, beet pulp was widely used for feeding cattle. Currently the demand of beet pulp that is used as cattle feed has declined due to the technological features of the feeding programs.

Beet pulp is optimally suited as organic matter for biogas production. However, its qualitative composition is not constant, it depends on the degree of its extraction, grinding, etc. The conditions of its storage are also an important factor. Therefore, it is advisable to study the energy properties of beet pulp and other by-products of agroindustrial complex proces sing enterprises. In addition, it is necessary to investigate various methods of raw material preparation, such as pressing, grinding, evaporation, in order to obtain the most suitable final product in terms of quality.

It is worth noting that crop waste itself can be used to produce solid biofuel, but to produce biogas, it must be mixed with animal waste.

Analysis of the theoretically possible yield of biogas from animal waste (cattle, pig, sheep, goat, horse and poultry manure) in Ukraine is given in Table 6. Taking into account the data on the output of biogas from 1 t of livestock waste (Kaletnik, 2018), the potential output of biogas from cattle waste may be 788.5 million $\mathrm{m}^{3}$, from pig manure 577.3 million $\mathrm{m}^{3}$, sheep and goats' manure -72.9 million $\mathrm{m}^{3}$, horses' manure -103.2 million $\mathrm{m}^{3}$, from poultry manure 1697.7 million $\mathrm{m}^{3}$. Thus, the total potentially possible output of biogas from lives tock waste in Ukraine is 3239.6 million $\mathrm{m}^{3}$.

\section{Potential output of biogas from livestock waste in Ukraine (on January 1, 2020)}

\begin{tabular}{|c|c|c|c|c|c|}
\hline Category & $\begin{array}{c}\text { Presence of } \\
\text { animals, thousand } \\
\text { heads }\end{array}$ & $\begin{array}{c}\text { Accumulation of } \\
\text { waste, } t \text { / year per } 1 \\
\text { head }\end{array}$ & $\begin{array}{c}\text { Accumulation of } \\
\text { total waste, million } \\
t / \text { year }\end{array}$ & $\begin{array}{l}\text { Biogas output } \\
\text { from } 1 \text { ton of } \\
\text { substrate, } \mathrm{m}^{3}\end{array}$ & $\begin{array}{c}\text { Biogas production } \\
\text { potential, million } \\
\mathrm{m}^{3} / \text { year }\end{array}$ \\
\hline Cattle & 3092.0 & 10.2 & 31.54 & 25 & 788.5 \\
\hline Pigs & 5727.4 & 3.6 & 20.62 & 28 & 577.3 \\
\hline Sheep and goats & 1204.5 & 1.1 & 1.32 & 55 & 72.9 \\
\hline Horses & 224.4 & 7.3 & 1.64 & 63 & 103.2 \\
\hline $\begin{array}{l}\text { Poultry (chickens, } \\
\text { geese, ducks, } \\
\text { turkeys) }\end{array}$ & 220485.8 & 0.055 & 12.13 & 140 & 1697.7 \\
\hline Total & $\mathrm{x}$ & $\mathrm{x}$ & 67.25 & $\mathrm{x}$ & 3239.6 \\
\hline
\end{tabular}

Source: calculated by the authors

Another potential supplier of feedstock for biogas production is the processing industry. Waste from distilleries, breweries and bioethanol plants differ in their characteristics and quantity, but all of these industries generate a significant amount of waste that can become a potential feedstock for biogas production. In distilleries, the waste product is post-alcoholic bard (corn or wheat). Beer bard is a waste of brewing (a thick residue that remains after brewing and filtering barley wort). The theoretically possible output of biogas from the waste of processing plants is given in Table. 7 . 


\section{Potential output of biogas from organic waste from processing plants in Ukraine (on January 1, 2020)}

\begin{tabular}{|c|c|c|c|c|}
\hline $\begin{array}{c}\text { Type of processing } \\
\text { plant }\end{array}$ & $\begin{array}{c}\text { Main type of waste } \\
\text { (by-products) }\end{array}$ & Total, million t / year & $\begin{array}{c}\text { Biogas output from 1 } \\
\text { ton of substrate, } \\
\text { cubic meters }\end{array}$ & $\begin{array}{c}\text { Biogas production } \\
\text { potential, million } \\
\text { cubic meters/year }\end{array}$ \\
\hline Breweries & Beer bard & 2.5 & 49 & 122.5 \\
\hline Sugar factories & Molasses & 0.6 & 166 & 99.6 \\
\hline Alcohol factories & Post-alcoholic bard & 1.1 & 55 & 60.5 \\
\hline \multicolumn{2}{|c|}{ Total } \\
\hline
\end{tabular}

Source: calculated by the authors based on the calculation methods of Kaletnik, 2018

A wide range of raw materials used for biogas production allows biogas plants to be built almost everywhere in areas where agricultural production and technologically related industries are concentrated. The versatility of the methods of energy use of biogas both for the production of electrical or thermal energy at the place of its formation. At the same time, the stability of electricity production from biogas throughout the year makes it possible to cover overloads in the network.

The calculation of the total potential of agricultural and processing waste for biogas production showed that a total of 13452.4 million cubic meters of biogas can be theoretically obtained, which is equivalent to 10761.9 million cubic meters of biomethane, which is identical in properties to natural gas (Table 8).

\section{Strategic potential of biogas production from agricultural waste and volumes of possible natural gas replacement in Ukraine}

\begin{tabular}{|c|c|c|}
\hline \multirow{2}{*}{ Indicator } & \multicolumn{2}{|c|}{ Value } \\
\hline & 2019 & $\begin{array}{c}2035 \\
\text { (forecast) }\end{array}$ \\
\hline Potential for biogas production from crop waste, million $\mathrm{m}^{3}$ & 9930.2 & 10923.2 \\
\hline Potential for biogas production from livestock waste, million cubic meters & 3239.6 & 3077.6 \\
\hline Potential for biogas production from organic waste of processing enterprises, million cubic meters & 282.6 & 316.5 \\
\hline Total potential for biogas production from waste, million cubic meters & 13452.4 & 14317.4 \\
\hline Potential for biomethane production from waste, million cubic meters $(80 \%$ of biogas yield) & 10761.9 & 11453.9 \\
\hline Volumes of natural gas consumption in Ukraine in $2019 / 2035$, million cubic meters & 29800.0 & 28012.0 \\
\hline Potential percentage of substitution of natural gas consumption, $\%$ & 36.1 & 40.9 \\
\hline The volume of natural gas imports to Ukraine, million cubic meters & 14200.0 & 13348.0 \\
\hline Potential percentage of substitution of natural gas imports, million cubic meters & 75.8 & 85.8 \\
\hline
\end{tabular}

Source: calculated by the authors

Full use of the theoretical potential of agricultural waste received in 2019 for biogas production would meet $36.1 \%$ of Ukraine's natural gas needs and replace $75.8 \%$ of imports of this type of fuel.

A forecast of the potential for biogas production from waste for 2035 using the expert and statistic methods is made, which is based on the following assumptions based on trends in Ukraine:

1. the volume of crop waste will increase due to the growth of gross crops in the use of efficient technologies in crop production, respectively, will increase the potential for biogas production; 
2. the potential for biogas production from livestock waste will decrease, as the number of animals in Ukraine has been decreasing for a long time; however, the rate of reduction will slow down due to state support of the industry;

3 . the volume of biogas production from organic waste of processing enterprises will increase due to the increase in the scale of raw material processing;

- due to the application of new energy-efficient technologies in various sectors of the economy and in households, the development of biogas technologies in Ukraine will reduce the consumption of natural gas and, accordingly, the volume of imports.

The strategic potential for biogas production from agricultural waste in 2035 will theoretically amount to 14317,4 million cubic meters, which will replace $40.9 \%$ of the total consumption of natural gas and $85.8 \%$ of its imports.

Thus, animal husbandry, crop production and many other processing industries involve a large amount of organic waste. The use of biogas digesting technologies at such enterprises allows to reduce the cost of maintenance, to obtain a balanced and nutrient-enriched fertilizer and to process industrial waste. Such installations are ecological, modern and high-tech designs that pay off very quickly and begin to give a net profit in short period of time. Biofuels are commonly used for heating, lighting, workshop maintenance, internal combustion engines, etc. By constructing a biogas plant at the production facility, the manufacturer frees himself from additional utility costs and creates his own energy base that meets the operational needs of the farm. It should be noted that reducing hazardous waste by recycling primary production waste is the only alternative to ensure high growth rates, considering the fact that the use of natural resources is limited.

The production of biogas from agricultural waste has a significant potential for heat and electricity generation due to the available residues of crop and livestock production in agriculture, favorable climatic conditions, the availability of agricultural land, a relatively inexpensive labor force and a large amount of agricultural waste from agricultural enterprises (Pryshliak, Tokarchuk\&Palamarenko, 2019).

Animal and poultry manure is a source of environmental problems if not handled properly. Environmental problems arise, as a rule, on industrial farms, which have a livestock of hundreds of thousands of animals or millions of poultry per year and, accordingly, thousands of cubic meters of waste. This waste is collected in lagoons and stored for several months to a year before being taken to the fields. In Ukraine, about $50 \%$ of livestock farms are industrial. When storing large volumes of waste in lagoons, unplanned leakage of manure into the environment is possible due to depressurization of the lagoons, flushing, exceeding the lagoon filling limits. In addition, manure can be applied to the soil at a frequency and in volumes exceeding the norm. With overtime application to the soil, entering groundwater and surface water, manure and dung are pollutants.

Manure also contains pathogens and bacteria that are resistant to antibiotics and can therefore spread diseases. About half of all drugs in the world are used in animal husbandry to prevent diseases. Manure and chicken dung are a source of ammonia, methane and other gases emissions into the air. When stored in open lagoons or applied to fields in large amounts, the local population living near industrial farms suffers from an unpleasant specific odor.

In addition to the unpleasant smell, emissions from industrial farms are harmful to the environment and cause climate change. The World Food and Agriculture Organization estimates that livestock is responsible for $18 \%$ of all human greenhouse gas emissions. That is more than emissions that come from transport. Animal manure is responsible for $7 \%$ of the total emissions of nitrous oxide, one of the most dangerous greenhouse gases.

Significant volumes of accumulated waste from agricultural enterprises in Ukraine and the lack of effective measures aimed at their further processing deepen the environmental crisis and become an inhibiting factor in the development of the national economy.

This situation makes it necessary to create and ensure the proper functioning of a nationwide system for the collection and environmentally safe processing of organic waste. This should be an urgent task even in conditions of relative limited economic opportunities for both the state and the main generators of agricultural waste. Thus, the only possible way to resolve the situation is to create an integrated waste management system for agricultural enterprises and organize biogas production on their basis.

The solution to this problem is key in solving the issues of energy and resource availability of the state, saving natural material and energy resources.

Unfortunately, in Ukraine, at the official level, statistics are not kept on the direction of waste use in biogas production. According to the National Commission for State Regulation of Energy and Utilities in 2020, there are 51 biogas plants in Ukraine with a total capacity of 96.7 MW (National Commission for State Regulation of Energy and Utilities). It should be noted that 5 years ago in Ukraine there were only 12 biogas plants with an installed capacity of 18 MW. In 2019, their number increased to 46, and the total capacity was up to $72 \mathrm{MW}$.

\section{Conclusions}

In the context of the financial and economic crisis, domestic agricultural enterprises face an important strategic task: on the one hand, to ensure profitable activities, on the other, to search the ways of development in the future, the basis of which is the effective management of agricultural waste for energy autonomy of agricultural enterprises.

The analysis of waste management of agricultural enterprises of Ukraine showed the following trends:

- the volume of waste generation in Ukraine is extremely high, which is associated with the use of outdated technologies in most sectors of the economy, a high level of resource consumption;

- accumulation of waste from agricultural enterprises, which has a negative impact on the environment and human health; The peak of agricultural waste generation was 2011 (at the level of 12.4 million $\mathrm{t}$ ), after which in the period of 2014-2016 the volumes fell to the amounts of 2010. In 2019, the volume of waste generation increased compared to the previous two years and amounted to 6.7 million $\mathrm{t}$. The share of waste from agriculture, forestry and fisheries in waste by type of economic activity and households in Ukraine ranges from $2-3 \%$;

- livestock and poultry is an important source of agricultural waste, where the main type of waste (byproducts) of agriculture is manure and bird dung;

- positive trends in the management of agricultural waste in Ukraine include the reduction of their disposal in specially designated places or facilities. However, for certain types of 
waste (residues from tree pruning and planting care, seeds of cereals and crops, excrement, urea and manure from livestock) the percentage of removal to landfills remains quite significant;

- implementation of improper processing of animal waste and processing enterprises, poses a significant threat to the environment due to emissions of methane into the atmosphere, pollution of grants and groundwater;

- inadequate level of waste use as secondary feedstock due to imperfection of the organizational and economic foundations of their involvement in production;

- the level of energy use of agricultural waste remains low, bioenergy potential is being lost;

- ineffective introduction of economic instruments in the field of waste management of agricultural enterprises.

Thus, the current situation in Ukraine, in particular with the problem of waste disposal and recycling, indicates a number of critical problems that require immediate and radical solutions.

A promising strategic direction for the use of agricultural waste is procession into biogas.

The strategic potential for obtaining biogas from agricultural waste in 2035 theoretically will be 14,317.4 million cubic meters, which can replace $40.9 \%$ of total natural gas consumption and $85.8 \%$ of its imports.

Using the energy potential of agricultural waste and organic waste from processing enterprises for the production of biogas, it is possible to significantly reduce the energy dependence of our state and, for a strategic perspective, to almost completely abandon the import of natural gas.

\section{References}

Berezyuk, S., Tokarchuk, D., Pryshliak, N. (2019a). Economic and Environmental Benefits of Using Waste Potential as a Valuable Secondary and Energy Resource. Journal of Environmental Management and Tourism, X, 1(33): 149-160.

DOI:10.14505/jemt.v10.1(33).15.

Berezyuk, S., Tokarchuk, D., Pryshliak, N. (2019b). Resource Potential of Waste Usage as a Component of Environmental and Energy Safety of the State. Journal of Environmental Management and Tourism. Issue 10 (5). P. 1157-1167. DOI:10.14505/jemt.v10.5(37).23.

Castillo-Gimenez, J., Montanes, A., and A. J. Picazo-Tadeo, A. J. (2019). Performance and convergence in municipal waste treatment in the European Union. Waste Management, 85, 222-231. DOI: 10.1016/j.wasman.2018.12.025

Heletukha, H. H., Zhelyezna, T. A. (2014). Prospects for the use of agricultural waste for energy production in Ukraine. UAB analytical note. Issue 7. P. 12-16.

Kaletnik, G. (2018). Production and Use of Biofuels. Second edition, supplemented. Vinnytsia: LLC "Nilan-Ltd". $336 \mathrm{p}$.

Kaletnik, G., Honcharuk, I., Okhota, Yu. (2020). The WasteFree Production Development for the Energy Autonomy Formation of Ukrainian Agricultural Enterprises. Journal of Environmental Management and Tourism. XI, № 3(43), 513-522. DOI: https://doi.org/10.14505//jemt.v11.3(43).02

Kaletnik, G., Pryshliak, V., Pryshliak, N. (2019). Public Policy and Biofuels: Energy, Environment and Food Trilemma. Journal of Environmental Management and Tourism. 2019. Issue X 3(35). P. 479-487. https://doi.org/10.14505/jemt.v10.3(35).01

Kulyk, M., Kurilo, V., Pryshliak, N., \& Pryshliak, V. (2020). Efficiency of optimized technology of switchgrass biomass production for biofuel processing. Journal of Environmental Management and Tourism. V. 11. Issue. 1. P. 173-185. DOI:10.14505/jemt.v11.1(41).20.

Obil, F. O., Ugwuishiwu, B.O., Nwakaire, J.N. (2016). Agricultural Waste Concept, Generation, Utilization and Management. Nigerian Journal of Technology (NIJOTECH), 35, 4, 957-964. doi: $10.4314 /$ njt.v35i4.34

Official website of the National Commission for State Regulation of Energy and Utilities (2021). Retrieved date of access $/ 09 / 01 / 2021 /$, from https://www.nerc.gov.ua/

Official website of the Sate Statistic Service of Ukraine. (2021). Retrieved date of access /09/10/2021/, from http://www.ukrstat.gov.ua/

Palamarenko, YA. V. (2019). Current state and prospects of development of the biogas industry of Ukraine. Investments: practice and experience. № 21. P. 54-62. DOI: 10.32702 / 2306-6814.2019.21.54

Pryshliak, N. (2019). Biogas production in individual biogas digesters: experience of India and prospects for Ukraine. Agricultural and ResourceEconomics: International Scientific E-Journal. 5(1). P. 122-136.

Pryshliak, N., Lutsiak, V., Tokarchuk, D., Semchuk, I. (2020). The Empirical Research of the Potential, Awareness, and Current State of Agricultural Waste Use to Ensure Energy Autonomy of Agricultural Enterprises of Ukraine. Journal of Environmental Management and Tourism. Issue 7 (47), vol. XI. P. 1634-1648. DOI:10.14505/jemt.v11.7(47).04.

Pryshliak, N., Tokarchuk, D. (2020). Socio-economic and environmental benefits of biofuel production development from agricultural waste in Ukraine. Environmental \& Socio-economic Studies. Volume 8. Issue 1. P. 18-27. https://doi.org/10.2478/environ2020-0003

Pryshliak, N.V., Tokarchuk, D.M., Palamarenko, YA.V. (2019). Ensuring energy and environmental security of the state through biofuels from bioenergy crops and waste: a monograph. Vinnytsia: Console. 336 p.

Sadh, P. K., Duhan, S., \& Duhan, J. S. (2018). Agroindustrial wastes and their utilization using solid state fermentation: a review. Bioresources and Bioprocessing, 5(1), 1. DOI: 10.1186/s40643-0170187-z

Tokarchuk, D. M., Pryshliak, N. V., Tokarchuk, O. A., Mazur, K. V. (2020). Technical and economic aspects of biogas production at a small agricultural enterprise with modeling of the optimal distribution of energy resources for profits maximization. INMATEH Agricultural Engineering. Issue 61(2). P. 339-349. DOI: https://doi.org/10.35633/inmateh-61-36

Zhang, Zh., Gonzalez A. M., Davies, E.G. R., Liu, Y. (2012). Agricultural Wastes. Water Environment Research, 84(10):1386-1406. DOI: $10.2175 / 106143012 X 13407275695193$

Zulauf, C., Prutska, O., Kirieieva, E., Pryshliak, N. (2018). Assessment of the potential for a biofuels industry in Ukraine. Problems and Perspectives in Management. Volume 16, Issue 4. P. 83-90.

DOI:http://dx.doi.org/10.21511/ppm.16(4).2018.08 